\title{
Toward a Model of Work-Related Self: A Narrative Review
}

\author{
Igor Knez*
}

Social Work and Psychology, University of Gävle, Gävle, Sweden

Occupational work as personal and social identification can be conceptualized as one of the life goals that we strive for and find meaning in. A basic categorization of the phenomenon of work-related identity is suggested, based on psychological theories of identity, memory and relational schema. It distinguishes between organizational, workgroup and professional identity. The two former relate to the concepts of social identity and collective self and the latter to the concepts of personal identity and individual self. These are assumed to form functionally independent cognitive structures, leading to separate motivations and influences on work-related satisfaction. Given this, empirical research on the impact of work-related identity on employee satisfaction, in general terms, is reviewed. The article concludes with some prospective directions for future research by sketching a general model of work-related self. It is hypothesized

OPEN ACCESS

Edited by:

Annamaria Di Fabio,

University of Florence, Italy

Reviewed by:

Dvaid Wilson Jamieson,

University of St. Thomas, USA

Alexander Kaiser,

WU - Vienna University of Economics

and Business, Austria

Letizia Palazzeschi,

University of Florence, Italy

*Correspondence:

lgor Knez

igor.knez@hig.se

Specialty section:

This article was submitted to

Organizational Psychology,

a section of the journal

Frontiers in Psychology

Received: 04 November 2015

Accepted: 22 February 2016

Published: 08 March 2016

Citation:

Knez I (2016) Toward a Model

of Work-Related Self: A Narrative

Review. Front. Psychol. 7:331.

doi: 10.3389/fpsyg.2016.00331 to evolve by a causal progression from employment across time via emotional and cognitive components.

Keywords: work-related identity, work-related-cognition, work-related emotion, work-related satisfaction, workrelated meaning, work-related self

\section{INTRODUCTION}

Employment is central to our lives. A large part of our waking life is related to occupational work and its life-long self-related construction (Guichard, 2009) and meaning (Cochran, 1991). It gives us social and economic status and brings prosperity to the common collective (Super, 1990). Organized labor also forms the foundation for personal health, development, and individual and social identity (Carr et al., 2003; Parker et al., 2003; Paul and Moser, 2009). According to Blustein (2006), it will gain even greater importance in the future due to employment's even more changeable form and content.

Humans are the only species that can plan for the future and meta-cognitively reason and reflect upon goals (type of "possible selves" - Markus and Nurius, 1986; Vignoles et al., 2008) such as those related to present and future employment. Thus, we do not, as other types of animal, relate only to the present needs of food and shelter. We think about and plan for long-term goals which may give us the meaning of, basically meaningless, life; at least according to existential philosophy (Camus, 1942). One such life-long objective is work per se; as Butler (1998, p. 70) pointed out: "Every man's [woman's - added] work... is always a portrait of himself [herself - added]."

We have all been asked: What will you be when you grow up? When we meet old friends that we have not seen for a long time, or when we, for that matter, get to know new people, we are often faced with similar questions: What do you do nowadays? An answer to such a question indicates our individual and social affinities, as well as the socio-economic category of these ties (Fouad and Bynner, 2008). Thus, and generally speaking, occupational work as personal and social 
identification, the career, can be conceptualized as one of the life goals that we strive for and find meaning in (Gini, 1998), analogous with Sisyphus rolling the boulder up the hill (Camus, 1942).

How we implement ourselves into work roles across a lifetime have been addressed by, for example, the career accounts (e.g., Cochran, 1992, 1997; Savickas, 2001, 2002, 2005) suggesting that a career is a "superordinate construct that allows people to construct connections among actions; to account for effort, plans, goals, and consequences" (Young et al., 2002, p. 2017). This phenomenon is also referred to as a type of self-related narrative, a "storied self" or a "narrative identity" (McAdams, 1995, 2006). It comprises recollections of our workand life-related experiences operating continuously in personenvironment interplay (Cochran, 1997; Bruner, 2004; Savickas et al., 2009) of interpersonal relationships, work roles and personal careers (Flum, 2001; Blustein, 2001; Blustein et al., 2004). For that reason, the concept of identity and the processes of identity adjustments and reconstructions are central to the career theory; accordingly, suggesting that we form and share our careers through our self-constructing narratives (Bujold, 2004; Di Fabio and Maree, 2013; Di Fabio and Bernaud, 2014).

\section{Aims of Review}

Corresponding, in general terms, to Ashforth et al. (2008) four fundamental identity-related questions: "What is identity?"; "Why does identity matters?"; How does identity evolve?"; and "Are there many or one identity?" this article has four aims. Firstly I review the research on identity, memory and the self ("What is identity and how does it evolve?"). I then review the research on work-related identity ("Are there many or one identity?") and work-related identity in practice ("Why does identity matters?").

Finally and given the previous reviews, I suggest a model of work-related self; "an individual work identity" (Walsh and Gordon, 2008). It includes an emotional component (involving process of work-related attachment/belonging/closeness) and a cognitive component (involving processes of work-related coherence, correspondence, temporality/mental time, reflection, agency). Work-related self is hypothesized to evolve by a causal progression from employment across employment time via emotional and cognitive components. It is general in its formulation, meaning that it is independent of different types of work-related identities. This suggests that a work-related self is a higher-order construct (Law et al., 1998; Stajkovic, 2006) capturing basic psychological processes grounding the associations between occupational work and the self; the self, which always strives for a meaning. This phenomenon is conceptualized as a knowledge structure resulting in a personal, autobiographical work-related experience of " $m y$ work" as opposed to the general concept (declarative knowledge) of "work" (Kihlstrom and Klein, 1994; Wilson and Ross, 2003; Conway and Holmes, 2004; Knez, 2014). Accordingly, this model relates to the Ashforth et al. (2008, p. 327) questions of "What is it?" and "How does it evolve?" even though they did "not consider personal identities."

\section{IDENTITY AND SELF}

Identity directs a person "to behave in certain ways" (Vignoles et al., 2008, p. 1166) and comprises two basic categories of personal and social identity. The former refers to our individual body and mental experiences. I am, in other words, a separate physical and psychological entity compared to other people, beings and things; an understanding that is constant over time. The latter type of identity refers to our membership of, belonging to, different social groups and contexts. Thus the social identity is associated with "group membership, group processes and intergroup behavior," and personal identity is associated with "close personal relationships and idiosyncratic attributes" (Hogg, 2003, p. 463). The type of identity that is of primary interest in the present article is personal and collective knowledge (Kihlstrom and Klein, 1994) of being a member of an occupational work context; especially, personal experience as referring to the general model of work-related self. This is in agreement with "the self as a knowledge representation" perspective, meaning that self-related information is apportioned across declarative memory (Klein and Loftus, 1993; Knez, 2014).

Psychological research in this area is extensive, including findings on identity in relation to its: (1) Form, content and organization; (2) Regulation and control; (3) Evaluation, motivation and emotion; (4) Interpersonal aspects; and (5) Phylo- and ontogeny-development (Leary and Tangney, 2003; see also Swann and Bosson, 2010 for a review). Personal and social identities can also be said to include and accommodate private and collective self, respectively, comprising self-concept and self-image, and the sense of continuity of "who I/we are" over time (Brewer and Gardner, 1996). Social identity can furthermore be characterized as a relational self, referring to personal ties such as a partner-relationship (Sedikides and Brewer, 2001); addressing the discussion of the primacy of the intra- or the interpersonal self (Tice and Baumeister, 2001).

Accordingly, we define, perceive and interpret ourselves by the operations of two basic psychological mechanisms of: (1) Being unique ( $m y$ body, memories, thoughts, opinions, feelings, experiences, sensations); and (2) Belonging to a group/social relationship (I am, e.g., journalist, father, woman, student, Englishman, fisherman).

\section{SELF AND MEMORY}

According to current developmental psychology, body-related self-consciousness starts at between 18 and 24 months of age (Anderson, 1984). Development of self-consciousness in the cognitive sense starts a little later and in parallel with language and episodic memory development (Fivush, 2011). Furthermore, this initiates the ability to travel in an inner mental world (McCormack and Hoerl, 1999). Consequently, young children up to 24 months of age are able to remember specific events and places, but these experiences will not be interpreted from the I/me perspective until the age of 3-4 years. 
Human long-term memory comprises two declarative/explicit memory systems (Squire, 1992). The episodic memory system contains the self-related (personal) information in a time and space perspective and semantic memory system stores all factrelated (impersonal) information (Tulving, 1972). Knowing that Stockholm is the capital of Sweden and that two plus two is four is hence stored in, and retrieved from, my semantic memory system, while my summer vocation memories from Stockholm might be recollected from my episodic memory system, or for that matter the information about when and where I learned that two plus two is four.

Different types of consciousness are also related to these memory systems (Tulving, 1985; but see also Henke, 2010). That is, I know and by that I am aware of (knowledge-related, noetic, awareness) that Stockholm is the capital of Sweden. I am also self-conscious (autonoetic awareness) about my summer experiences in Stockholm; in other words, I remember these personal experiences. Accordingly, when we talk about personal involvement we retrieve that information from episodic memory (e.g., "I remember when I defended my Ph.D. thesis."), while impersonal facts are recollected from semantic memory (e.g., "I know what a Ph.D. degree means.").

The relationship between memory and the self has long engaged various philosophical and psychological schools (see Klein, 2012 for a review). One could, in general terms, say that the relationship between memory and the self is reciprocal. That is, we are what we remember, and vice versa. Self is, therefore, a product of its past, its memories (Locke, 1690/1849; Grice, 1941; Klein, 2001). Further, remembering presupposes a self, an agent that remembers/knows (James, 1890/1950; Wheeler et al., 1997; Suddendorf and Corballis, 2007); as pointed out by Tulving (1985, p 15): "It is the self that engages in the mental activity that is referred to as mental time travel: there can be no travel without a traveler."

Autobiographical memory handles relationships between memory and the self. It is a system, a knowledge representation (Kihlstrom and Klein, 1994) that manages the psychological blocks of the self, such as coherence in the self across time, its social information base, and self-targeted behaviors and problem solving (Bluck et al., 2005; Conway, 2005). The autobiographical information is distributed across declarative memory as impersonal information (Ph.D. degree as a concept is stored in semantic memory) and personal information (when and how I defended my Ph.D. thesis is stored in episodic memory). More precisely, within episodic memory system the self-related memories are associated with the sense of personal identity across time and space, and within semantic memory system the self-related memories are associated with the factual and trait- based self-knowledge (Klein and Gangi, 2010; Klein and Lax, 2010). In the words of Klein (2013, p. 3): "We are acquainted with semantic pastness indirectly via inference, whereas our acquaintance with episodic pastness is directly given as the feeling that we are re-living our past."

The experiential, phenomenological dimension of these "reliving" operations is often characterized as a personal life story (Habermas and Bluck, 2000; Fivush, 2008). Thus, when we remember we tell a story, in a broad sense. It contains different types of themes/chapters (e.g., work, education, relationships, and places) around which the personal experience information is grouped and retrieved (Williams et al., 2008; Knez, 2014). For example, if I recall "my first girlfriend" I can recount where and how we met, her name, what she looked like, where she lived, what music we used to listen to, what friends we hung out with, etc (see Prebble et al., 2013 for a recent account of self and memory).

The self as "a knowledge representation" perspective does also imply that we may have several "context-specific" selves (McConnell, 2011) and that "autobiographical self is not a mere list of episodic memories, but more likely a narrative structure that includes the temporal and causal relations among remembered events" (Kihlstrom, 2012, p. 367). In the words of Gao and Riley (2009, p. 325): “. . knowledge has a place in the individual's cognitive identity structure and, consequently, a role in identity formation." Finally, the neural structure accounting for the self-referential information processing is the medial prefrontal cortex (D’Argembeau and Salmon, 2012).

\section{WORK-RELATED IDENTITY}

Given the above, we could say that humans unlike animals (Markowitsch and Staniloiu, 2011) have two basic psychosocial needs of: (1) Distinguishing us from others in order to preserve the personal self, the personal story and its memories (Brewer, 1991); and (b) Belonging to a social group, a social context, in order to be part of the collective self, the collective story and its memories (Brewer and Gardner, 1996). Further, and according to social identification theory (Tajfel and Turner, 1979, 1986; Pratt, 1998; Jackson, 2002; van Dick, 2004; Ellemers et al., 2004) the following three mechanisms operate on behalf of a healthy self and social identity: (1) Thriving toward positive self-evaluation; (2) Linking social affiliations to self-concept and social identity; and (3) Retaining and strengthening positive social group identity, by in- vs. out-group comparisons. These additionally interact (Boros et al., 2011) across: (1) Knowledge related to person's social identification; (2) Emotional links developed to various social groups; (3) Valuations of in- vs. out-group distinctions; and (4) Behavioral sets tied to different social identifications.

Organized labor is, as mentioned above, essential for a person's self-worth, meaningful and healthy life (Ashforth and Mael, 1989; Fine, 1996; Gini, 1998; Paul and Moser, 2009). For that reason it constitutes a pivotal social context within which individuals seek multidimensional (Ashforth and Mael, 1989) loyalties (Reichers, 1985; Becker et al., 1996); coalitions labeled as organizational, workgroup and professional identity (Causer and Jones, 1996; Cappelli, 2000; Day et al., 2006; Johnson et al., 2006; Pate et al., 2009). Accordingly, the multiple self-concept representations (Neisser, 1988; McConnell, 2011) of professional identity are related to personal identity ("My profession, career, as a lecturer." = personal self) and working group ("We lecturers working at the Department of Psychology.") 
and/or organizational identities ("We lecturers working at the Faculty of Behavioral Sciences.") are related to social identity (collective self).

Thus and in an organized labor context, individual identity is associated with self-related interests and motivation (personal self). It generates behaviors that mirror personal attitudes, aspirations, and goals (Ybarra and Trafimow, 1998). Social identity, on the other hand, is associated with attitudes, norms and behaviors related to a group's identity, to its collective self (Hogg, 2006; Jackson et al., 2006). Accordingly, this is in line with the self-categorization theory (e.g., Turner et al., 1994) suggesting a distinction between personal identity (personal self) and social identity (collective self) indicating that individual and social identity incorporates two functionally independent cognitive structures of self-representations (personal vs. collective), leading to different self-related interpretations and definitions (Sedikides and Brewer, 2001). This does not, however, suggest that the private and collective selves are unconnected, but that: “...one system can operate independently of the other, though not necessarily as efficiently as it could with the support of the other intact system." (Tulving, 1983, p. 66); meaning that "self-concepts can take different forms at different levels of abstraction" (Onorato and Turner, 2004, p. 276)

We also strive for positive work-related allegiances (Gecas, 1982; Turner, 1982; Bartel and Dutton, 2001), as positive identity construction may, for example, enhance well-being (Caza and Wilson, 2009) and creativity (Cheng et al., 2008), as well as promote career adaptation/development (Ibarra, 1999). According to Dutton et al. (2010) four theoretical perspectives capture the positivity in work-related identity; namely, virtue perspective (e.g., courage, humanity, justice), evaluative perspective (feelings of self-regard increasing/maintaining the self-worth), development perspective (progress/adaptation in identity development), and structural perspective (balance in multidimensional loyalties).

Yet, one important factor to consider is that organizational and workgroup identities are not everlastingly settled. Persons can sometimes feel greater affinity with their workgroup compared to the organization and sometimes vice versa, depending on the strength of the identification and positioning of we and they classifications that evolve and change across time and workplace (Wagner and Ward, 1993; van Dick, 2004).

Finally, work-related identification implies not only individual and social classifications, but relationship patterns too. These are collections of knowledge structures (scripts/schemas stored in semantic memory) related to particular situations; such as, "attending a business meeting." A script/schema of this kind gives us all the different social processes that usually occur when we are attending a business meeting. This mental representation serves as a guide for our perception, interpretation, and understanding of the situation at hand and the people involved (Bartlett, 1932; Higgins and Bargh, 1987). When it comes to work-related identity, a script/schema would then instruct our perceptions and interpretations of in- and/or out-group interactions and situations (Baldwin, 1992; Terry and Hogg, 1996).

\section{WORK-RELATED IDENTITY IN PRACTICE}

Given the above, we may predict that similar values, beliefs and standards will be found in individuals sharing a strong ingroup identity (Tajfel, 1978; Mael and Ashforth, 1992). Previous research has indeed indicated that the stronger the group identification an individual feels, the more that group will influence his/her attitudes and behaviors (Hogg and Abrams, 1988). Employees with weak organizational identity will, for example, not engage in the instructions and information that the organization communicates, because they have too weak organizational identity (Mobley et al., 1979). They simply do not share organizational values (Johnson and Jackson, 2009). It has also been shown that social group identification is central to Internet-based work, although individuals never meet in reality (Michinov et al., 2004). Work-related identity has also been indicated to mediate effects of organizational justice on trust and cooperative behavior (Johnson and Lord, 2010).

Accordingly, it is difficult to fully understand employees' work-related behaviors if we do not take into account their occupational identities (Vondracek et al., 1986; van Dick, 2004; Edwards, 2005; Wayne et al., 2006; Gao and Riley, 2009; Greenhaus et al., 2012; Ravasi and Canato, 2013; Brown, 2014). Why? This is because personal and social identifications are profoundly involved in formations of work-related self-image, self-esteem, motivation, task perception and valuation of future professional perspectives (Kelchtermans, 1993), as well as with operational efficiencies and strategic agreements (Sinclar, 2008). Concerning self-image and self-esteem issues, Lipponen et al. (2005) have indicated an impact of perceived prestige on workgroup identification, showing that high group reputation is associated with strong group identification. Obschonka et al. (2012) have additionally suggested that entrepreneurship may be a function of: (1) Social norms in individuals with a strong work-group identity; or (2) Personal initiative and control in individuals with weak work-group identification.

\section{Adult Development and Work-Related Identity}

Formation of work-related identity coincides with adult identity establishment (Marcia, 1980; Blustein et al., 1989), stabilized around 20-30 years of age (Arnett, 2000, 2004; Plug et al., 2003). It consists, roughly, of four phases (Savickas, 1985): (1) Diffusion ("I don't really know what I want to do/be."); (2) Precursor ("Well I'll check this type of work."); (3) Moratorium ("I'll try to develop within this profession."); and (4) Performance/commitment ("I know what I want to do/be"). The formation of a work-related identity is assumed to be "completed" during the person's $30 \mathrm{~s}$ (Plug et al., 2003; Arnett, 2004).

This process is not just about a young person entering the world of employment but is also related to voluntary (personal motivation, aspiration, and ambition) and involuntary (institutional and situational constraints) work-related transitions (Foud, 2007). Luyckx et al. (2010) have shown that strong personal identity in young adults correlates highly 
with work-related commitment and low risk of work-related depression. This suggests that the formation of a personal identity goes hand in hand with psychosocial adjustments (Kroger, 2007), and that work-related identity is an important part of the formation of an adult identity (Skorikov and Vondracek, 2007).

\section{Demographic Variables and Work-Related Identity}

Men put more emphasis on salary, power, and career. They also spend more time working (Greenhaus et al., 2012); which female and male managers also do (Brett and Stroh, 2003). Gender is also involved in work-related identity issues (Sluss and Ashforth, 2007). According to social identity theory, we might predict that gender as a homogeneous group (in-group) would show strong group identification; e.g., operationalized as group commitment and cohesion (Williams and O'Reilly, 1998; Swann et al., 2004). Van Knippenberg et al. (2007) have shown, however, that gender group identification may be more related to beliefs about gender related diversity/homogeneity than to group homogeneity per se. They reported that gender diversity (male + female group composition) compared to gender homogeneity (male vs. female group composition) was associated with higher levels of workgroup identity.

Becoming a part of a new social context and hence acquiring new work-related identities has also been investigated in studies addressing globalization issues, indicating different career paths across geographical and cultural boundaries (Cohen et al., 2011; Flum and Cinamon, 2011) that may be linked with age and ethnic changes in society. This has, for example, already happened in Great Britain (Kenny and Briner, 2007). It is estimated that 50\% of the future workforce will be composed of minority ethnic groups (which is only $8 \%$ of the population) due to these groups' younger age composition (Cabinet Office Strategy Unit, 2003).

\section{Work-Related Satisfaction and Work-Related Identity}

Previous findings have shown that organized labor is related to physical and mental health and, conversely, that unemployment is associated with physical and mental illness (Murphy and Athanasou, 1999; Friedland and Price, 2003; Paul and Moser, 2009). It has also been indicated that personal well-being and happiness take some time to recover after a period of unemployment (Lucas et al., 2004). Correspondingly, workrelated identity has been reported to associate with work-related support (Mael and Ashforth, 1995), commitment (Baruch and Cohen, 2007), performance and motivation (Haslam et al., 2000), group relations (van Knippenberg, 2003), organizational mergers (Haslam, 2001), changes (du Gay, 1996), learning (Collin, 2008), organizational justice (Olkkonen and Lipponen, 2006), and with the appreciation of the work per se (Collin et al., 2008). Escartín et al. (2013, p. 182) have also indicated that "the more employees identified with their group, the less likely they were victims of bullying." Thus, work-related satisfaction, in general terms, is strongly linked to work-related identity (Fenwick, 2004; Kirpal, 2004).
Strong work-related identity can, however, be difficult to change in cases of reorganization, for example, because it takes some time to break up and create new identities and loyalties (van Dick et al., 2006; van Vuuren et al., 2010). A process that can also generate stress among employees (Jetten et al., 2002) and lead to decreased confidence, motivation, commitment, and performance (Haslam, 2001). Employees may, in other words, lose their personal feelings of control, meaningfulness and identification with the workplace (Ashforth, 2001).

Concerning the relation between work-group identity and work-group size, some findings have indicated a tendency to a stronger identification with smaller rather than larger workgroups (van Knippenberg and van Schie, 2000; Riketta and Dick, 2005). In particular it is shown that identification with a group correlates highly with work-related job satisfaction (van Knippenberg and van Schie, 2000). This is in line with some research on work-group size that has shown that the smaller the group, the stronger the workgroup identification (Mullen, 1991; Lipponen et al., 2005).

Work-related identity has also been found to mediate individual work-related learning with adaptation (Sfard and Prusak, 2005; Kirpal et al., 2007). Employees' work-related self-assessment has been shown to increase as a result of leaders' work-related self-sacrifice coupled with strong workrelated identity in employees (Cremer et al., 2006). Work-related engagement (Buchanan, 1974; Staw and Salancik, 1977; Mowday et al., 1982), motivation and performance have also been reported as being associated with work-related identity (van Knippenberg, 2000; Mathews and Shepherd, 2002).

Motivation is especially important in this context. It has been reported that people with a weak group identity "mimic" others' behaviors, while individuals with a strong group identity contribute more to the group if others "slip by" (Fishbach et al., 2011). This implies that when a group weakens its position, individuals with a weak group-identity will withdraw from the group so as not to risk something personal, while individuals with a strong group-identity will sacrifice more in order to maintain the status of the group (Tajfel and Turner, 1979).

Previous research has furthermore indicated an association between work-related identity and health/well-being (Haslam et al., 2009; Wegge et al., 2012). Strong occupational identity can also function as a buffer against stress (Haslam, 2001). Wegge et al. (2006) reported a relationship between work-related depression, satisfaction and hectic work environment, showing an association between strong work-related identity and a small number of cases of depression and high occupational satisfaction. A link between work-related identity and burnout has also been indicated (Luyckx et al., 2010), suggesting that burnout may increase when professional identity decrease (Edwards and Dirette, 2010).

Two other important factors related to work-related identity are perceived justice and economic earnings. These have been shown to have a strong effect on employee behavior and engagement, especially with regard to extra work that an employee is willing to perform (Blader and Tyler, 2005, 2009). Thus, it is vital for an employer to behave fairly toward employees and financially reward their work. In line with this, Cremer 
(2006) has shown that individuals with a strong organizational identity will be disappointed when treated unfairly, leading to acts of revenge against management when perceived disappointment is "sufficiently" great. Other results have also indicated that negative emotions may be associated with unfair treatment (Tripp and Bies, 1997), sabotage (Ambrose et al., 2002), strikes (Leung et al., 1993), and revenge (Skarlicki and Folger, 1997).

It may thus be the case that employment as a social context is an important factor for individuals' work-related meaning and satisfaction (Aamondt, 2009), and that it is strongly related to the phenomenon of work-related identity (Smith et al., 1969; Hackman and Oldham, 1980). Satisfied employees are usually more often at work than those who are not (Johns, 1997; but see Diestel et al., 2013), perceiving their occupational work as a part of themselves; as my castle, an analogy with the expression of "my home is my castle" (van Dick, 2001). Accordingly, people with a strong work-related identity will perceive their occupational work in terms of my work (my castle); as Gini (1998, p. 714) pointed out: "Descartes was wrong. It isn't Cogito ergo sum, but, rather, Laboro ergo sum. We need work, and as adults we find identity and are identified by the work we do."

\section{RECOMMENDATIONS FOR FUTURE RESEARCH}

Given that we strive for both personal and social identities (Sedikides and Brewer, 2001), one important issue that previous research has as yet not fully addressed is whether employees can have multiple, equally strong occupational identities (Pate et al., 2009); and how these types of identity are linked to personal and social selves (Onorato and Turner, 2001; Sedikides and Gaertner, 2001; Smith et al., 2001; Spears, 2001; Tice and Baumeister, 2001; Ashforth et al., 2011) and personal careers (Di Fabio and Maree, 2012; Di Fabio and Saklofske, 2014; Di Fabio and Kenny, 2015)? One way to approach this question within work and organizational research (Blader et al., 2007) would be to study associations between personal, relational and collective selves with types of work-related identity (Reid and Deaux, 1996; Farmer and Van Dyne, 2010), and how these constructs are organized in autobiographical memory (Knez, 2006; Williams et al., 2008).

Cognitive, emotional and behavioral components of personal and social identification (Kidd, 1998; Ellemers et al., 2004; Boros et al., 2011) should also be included in future analyses, especially related to the processes of construction and maintenance of an identity. Furthermore it is important to focus on workrelated identity and satisfaction in relation to work-related justice (Johnson and Lord, 2010), leader/employee perspectives (George, 1995; McLain, 1995; Siegall and McDonald, 1995) and demographic variables (Kim and Gelfand, 2003; Kavanaugh et al., 2006; Kenny and Briner, 2007; Sluss and Ashforth, 2007; Cohen et al., 2011).

Finally, some of the previous research on identity and memory (Knez, 2005, 2006, 2014) has recognized concepts of time and attachment/belonging/closeness as two central factors in identity formation. It would therefore be of interest to transfer these theoretical ideas and empirical results to the context of workrelated identity. Given this, I will below sketch a general model of the phenomenon of work-related self.

\section{TOWARD A MODEL OF A WORK-RELATED SELF}

"From the approximate ages of 21-70 we will spend our lives working... like Sisyphus we are all condemned to push and chase that thing we call our job, our career, our work all of our days" (Gini, 1998, p. 707). Work/employment is "a pervasive life domain and a salient source of meaning and self-definition" (Dutton et al., 2010, p. 265). Accordingly, the phenomenon of occupational work is central to human life, involving considerations of purpose and meaning(fullness) of work (Hackman and Oldham, 1976; Schwartz, 1999; Wrzesniewski et al., 2003; Heine et al., 2006; Grant, 2008; Rosso et al., 2010); that may affect, for example, work-related motivation (Roberson, 1990), well-being (Ryan and Deci, 2001), engagement (May et al., 2004), and career development (Dik and Duffy, 2009). Hence: "The more involved one is with the job, the more difficult is to dissociate oneself. . f from that job” (Rosso et al., 2010, p. 97).

Given that: (1) The self is a "complex system of active and interactive self-organizing processes" (Mahoney, 2002, p. 747); (2) Autobiographical memory manages the psychological blocks of the self, involving several context-specific selves and integrating emotional and cognitive processes in a goal-directed manner; (3) Individual and social identity incorporates two functionally independent, but interacting, cognitive structures of self-representations; (4) Individual self is the "home base" for selfdefinitions constituting the "essence of the person," because "the level of individualism is relatively stable and invariant," meaning that it is "less amenable to variation due to culture" (Sedikides and Gaertner, 2001, p. 19,20), I suggest a higher-order work-related identity construct, the working-self, capturing basic psychological, individual mechanisms accounting for the occupational workself associations. This is in accordance with the definition of the "healthy and stable self" (Conway et al., 2004; Klein et al., 2004); a perspective that has, as far as I know, not been previously addressed by any account in occupational and organizational psychology regarding the phenomenon of work-related identity.

\section{Model Components}

Previous findings in identity, self and memory research have shown that the course of self-formation involves factors of time, attachment/belonging/closeness, coherence, correspondence, temporality (mental time), reflection and agency (e.g., James, 1890/1950; Klein et al., 2004; Conway, 2005; Knez, 2014). These, in addition, interplay with social contexts of, for example, geographical location (Knez, 2014) and employment; a "work theme" (Williams et al., 2008). Given that affect plays a crucial role in meaning of life and identity formation (King et al., 2006; Burke and Stets, 2009) and that previous research on workrelated identity has predominantly been focused on cognitive aspects (see Edwards, 2005 for a discussion), the present model will include (as suggested by, for example, van Dick, 2004; 
Edwards, 2005; Burke and Stets, 2009; Rosso et al., 2010) both "employee's thoughts and feelings that have reference to himself [herself - added]" (Rosenberg, 1979, p. 7).

The conceptual model of work-related self (see Figure 1) encompasses time and two basic psychological elements: (1) Emotional component comprising the process of work-related attachment/belonging/closeness; (2) Cognitive component comprising the processes of work-related coherence, correspondence, temporality/mental time, reflection, and agency.

Time is included due to its relation to work orientation (Rosso et al., 2010) and because identity “...depends, in fundamental way, on our capacity to represent the self as a psychological coherent entity persisting through time" (Klein et al., 2002, p. 353). Similarly, Kant (1787/1929) defined time as one of the basic formats for the structuring of human experience (see also Klein, 2014a for a discussion about the phenomenon of "sameness," that is, how we across time feel that we are the same?). In addition, Goodman et al. (2001, p. 507) pointed out that "there is surprisingly little research on time" in organizational life research.

The model is general in its formulation, meaning that it is independent of different types of work-related identities. Accordingly, work-related self is a higher-order construct (Law et al., 1998; Stajkovic, 2006) that captures the basic psychological processes grounding the associations between the occupational work and the self. This phenomenon is conceptualized as a knowledge structure comprising the personal information (Kihlstrom and Klein, 1994; Wilson and Ross, 2003; Conway and Holmes, 2004; Knez, 2014) of " $m y$ work" as opposed to the declarative knowledge of the "work" concept. In the words of Kihlstrom et al. (2003, p. 69): “The self is a mental representation of oneself, including all that one knows about oneself. The $I$ who knows the me is the same $I$ who knows everything else, and the mental representation of this knowledge is no different, except perhaps in intimacy and richness, than is the mental representation of anything else I know.”

The main function of the work-related self is to emit the autobiographical experience of " $m y$ work" ( $m y$ castle; van Dick, 2004). As can be seen in Figure 1, work-related self is grounded in the social context of employment across time; it is thus "an individual work identity" (Walsh and Gordon, 2008) based on the interactions between work and work-related identifications (Kira and Balkin, 2014). Its main function is to guide personal reminiscence and self-knowing consciousness related to the work context; that is, to the autobiographical theme of occupational work (Conway, 2005; Williams et al., 2008) distributed across declarative memory as impersonal (employment/work as a concept) and personal (my employment/work) information (Klein et al., 2004; Bluck et al., 2005) about our work experiences. The two psychological forces accounting for the construction of the work-related self are the emotional and cognitive components involving the selfformation processes of attachment/belonging/closeness, coherence, correspondence, temporality (mental time), reflection and agency (e.g., James, 1890/1950; Conway et al., 2004; Klein et al., 2004; Conway, 2005; Knez, 2014).

The processes defining emotional and cognitive components, below, relate to the fundamental question of "who one is?" paralleling the concepts of sensebreaking/sensegiving and/or claiming/granting in organizational identity construction literature (Weick, 1995; Pratt, 2000, 2001; Wrzesniewski et al., 2003; Ashforth et al., 2008).

\section{Emotional Component}

The impact of a caregiver-infant relationship on infancy and early childhood has been addressed by attachment theory (Sedikides and Skowronski, 2003). This frame of reference cannot, however, be converted analogously from the caregiver-infant relationship to the vocational behavior context; because, the latter indicates a one-way closeness between a person and its occupational work as opposed to the former which designates a reciprocal link between an infant and a caregiver (Bowlby, 1988). Attachments, in general terms, are: "relationships. . .to particular people whom we love ... and sometimes to particular places that we invest with some loving qualities." (Marris, 1982, p. 185); meaning that "individuals identify by seeking to experience a sense of pride, warmth, or affirmation" (Ashforth et al., 2008, p. 343; see also Harquail, 1998). Thus, if we assume that "place," in

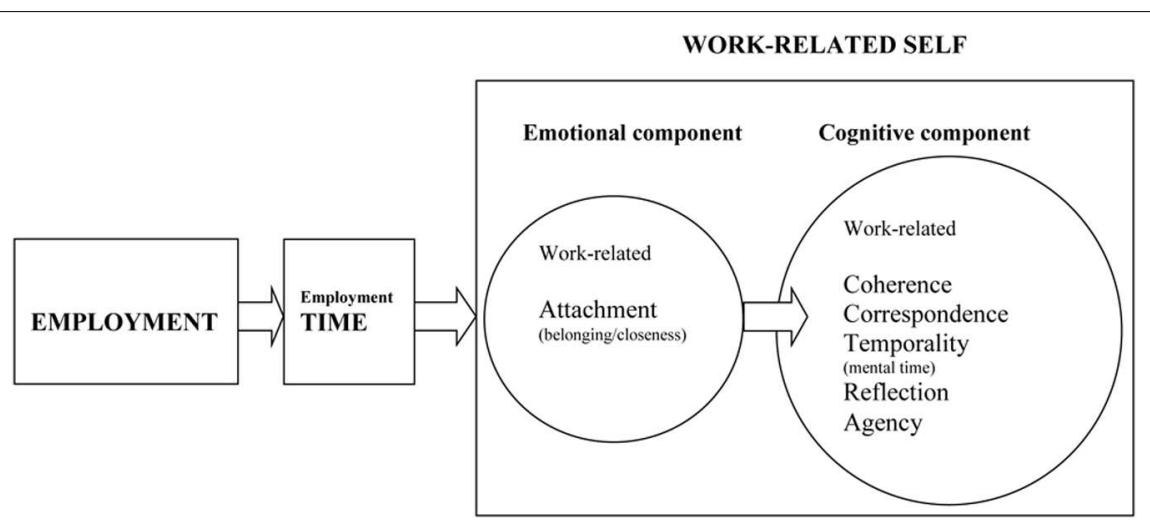

FIGURE 1 | Causal formation of work-related self; from employment across employment time to work-related emotional (attachment/belonging/closeness) and cognitive (coherence, correspondence, temporality/mental time, reflection, agency) components. 
Marris' (1982) words, correspondence to "employment," we could subsequently posit a one-way closeness (attachment) between a person and its employment (see Knez, 2014 for this type of argument), indicating an employee's affection to its occupational work (Meyer and Allen, 1991; Johnson and Jackson, 2009).

\section{Cognitive Component}

The concept of coherence signifies "rationality" (Hammond, 2007) or "conservatism" (Greenwald, 1980) of the self (continuity in the self across time, in James' terms), and correspondence refers to the on-going processes of "accurate/adaptive" interactions between the self and its contexts (Conway et al., 2004). Furthermore: "We feel and act about certain things that are ours very much as we feel and act about ourselves." (James, 1890, p. 291). These words capture the two "necessary components" of the healthy self and its processes of autobiographical recollection as suggested by Klein et al. (2004); the third one is selftemporality (temporality/mental time). Thus, and in order to coherently and correspondingly ground the working-self across employment time, the person must also be aware of, and reflect (reflection) upon, her/his (agency) mental states as related to the work contexts; standpoints that also coincide with Erikson's (1968) reasoning about the defining-and-meaningfulidentity (the self) comprising components of inner continuity, consciousness and agency across time.

In sum, a general framework for the phenomenon of work-related self is sketched. This account proposes (see Figure 1) that the transformation of "work" (declarative fact with accompanying noetic consciousness) to "work of mine" (personal fact with accompanying autonoetic consciousness) is due to an amalgamation of employment, employment time and psychological processes of work-related attachment/belonging/closeness, coherence, correspondence, temporality, reflection and agency. Accordingly, the model predicts that the organization will "in effect, been incorporated into the self-concept... the organization becomes a part of the individual's self-concept." (Edwards, 2005, p. 213). Practically, this means that when a manager, for example, plans to reconstruct a department or teamwork the employees' work-related selves (identifications) will matter (van Dick, 2001).

Given that managers "are people who do things right" (Bennis and Nanus, 1985, p. 221) related to functions of planning, budgeting, organizing, staffing, controlling, and problem solving (Kotter, 1990) and that role modeling plays a part in identity construction (Shapiro et al., 1978), we may say that $I$, for example being a senior female manager and a role model (Sealy and Singh, 2009), across employment time have evolved an attachment (belonging/closeness) toward my position (employment) and by that have initiated my work-related self. Reflecting upon these

\section{REFERENCES}

Aamondt, M. (2009). Industrial-Organizational Psychology. Bellmont, CA: Cengage Learning.

Ambrose, M. L., Seabright, M. A., and SChminke, M. (2002). Sabotage in the work place: the role of organizational justice. Organ. Behav. Hum. Decis. Process. 89, 947-965. doi: 10.1037/a0012704 experiences (memories) of mine (agency) I remember (I'm selfknowingly consciousness about this personal chronicle) the date (inner temporality) when I became a manager (coherence) and by that a role model for other women, struggling with "rigid and male-dominated hierarchies" (Sealy and Singh, 2009, p. 284).

As a consequence of all this, $I$ will plan to increase the "pool of available female role models at board director level" (Sealy and Singh, 2009, p. 285) [an accurate correspondence with the on-going present; indicating "congruence between self-at-work and one's broader self-concept" (Rousseau, 1998)]. So, when I think/speak about my work $I$ mentally re-live the experiences of "my castle" (van Dick, 2004); meaning that $I$ feel good about my work, as well as that my work is a part of myself because autobiographical memory by definition "entails a mental representation of the self” (Klein, 2014b, p. 19).

\section{CONCLUSION}

Accordingly, the model hypothesizes (see Knez, 2005, 2014), that across employment time we evolve an emotional tie to our work (prediction: the more time the stronger emotional link). Secondly, given that the emotion may modulate better retention in episodic memory (Canli et al., 2000), the model also predicts that the emotional connection may precede the cognitive one because personal memory (in this context, "work of mine") may be more easily recalled due to its emotional connotations stored in the autobiographical knowledge base (Welzer and Markowitsch, 2005).

In line with Knez (2014, p. 170) reasoning, we could conclude that how I (the knower; the ontological self) ground my working-self (the known; the epistemological context-specific self) requires that: (1) I across employment time evolve an emotional tie (attachment/belonging/closeness) to my work; (2) I represent my working-self across employment time as a coherent self, (3) appropriately corresponding to the immediate ongoing work-related reality, and (4) that I am reflective upon and (5) aware of me as possessing my inner work-related world in a (6) time-related unfolding of my work-related experiences. All this is done within the context of a goal-driven autobiographical representation of the working-self.

Finally, this is no more than a conceptual model, which means that several studies are needed to test these ideas in more empirical detail.

\section{AUTHOR CONTRIBUTIONS}

The author confirms being the sole contributor of this work and approved it for publication.

Anderson, J. A. (1984). The development of self-recognition: a review. Dev. Psychobiol. 17, 35-49. doi: 10.1002/dev.420170104

Arnett, J. J. (2000). Emerging adulthood: a theory of development from the late teens through the twenties. Am. Psychol. 55, 469-480. doi: 10.1037/0003066X.55.5.469

Arnett, J. J. (2004). Emerging Adulthood: The Winding from Late Teens Through the Twenties. Oxford: Oxford University Press. 
Ashforth, B. E. (2001). Role Transition in Organizational Life: An Identity-Based Perspective. Mahwah, NJ: Erlbaum.

Ashforth, B. E., and Mael, F. (1989). Social identity theory and the organization. Acad. Manag. Rev. 1, 20-39. doi: 10.5465/AMR.1989.4278999

Ashforth, B. E., Rogers, K. M., and Kevin, G. C. (2011). Identity in organizations: exploring cross-level dynamics. Organ. Sci. 5, 1144-1156. doi: 10.1287/orsc. 1100.0591

Ashforth, B. E., Spencer, H. H., and Kevin, G. C. (2008). Identification in organization: an examination of four fundamental questions. J. Manag. 3, 325-374. doi: 10.1177/0149206308316059

Baldwin, M. W. (1992). Relational Schemas and the processing of social information. Psychol. Bull. 3, 461-484. doi: 10.1037/0033-2909.112.3.461

Bartel, C., and Dutton, J. E. (2001). "Ambiguous organizational memberships: constructiong organizational identities in interactions with others," in Social Identity Processes in Organizational Contexts, eds M. A. Hogg and D. J. Terry (Philadelphia: Psychology Press), $115-130$.

Bartlett, F. C. (1932). Remembering: A Study in Experimental and Social Psychology. Cambridge: Cambridge University Press.

Baruch, Y., and Cohen, A. (2007). "The dynamics between organizational commitment and professional identity formation at work," in Identities at Work, eds A. Brown, S. Kirpal, and F. Rauner (Dordrecht: Springer),241-260.

Becker, T. E., Billings, R. S., Eveleth, D. M., and Gilbert, N. L. (1996). Foci and bases of employee commitment: implications for job performance. Acad. Manage. J. 2, 86-91.

Bennis, W. G., and Nanus, B. (1985). Leaders: The Strategies for Taking Charge. New York, NY: Harper \& Row.

Blader, S. L., and Tyler, T. R. (2005). "How can theories of organizational justice explain the effects of fairness?, in Handbook of Organizational Justice, eds J. Greenberg and J. A. Colquitt (Mahwah, NJ: Erlbaum), 329-354.

Blader, S. L., and Tyler, T. R. (2009). Testing and extending the group engagement model: Linkages between social identity, procedural justice, economic outcomes and extrarole behavior. J. Appl. Psychol. 2, 445-464. doi: 10.1037/a00 13935

Blader, S. L., Wrzesniewski, A., and Bartel, C. A. (2007). "Identity and modern organization: an invitation," in Identity and the Modern Organization, eds C. A. Bartel, S. Blader, and A. Wrzesniewski (Mahwah, NJ: LEA), 3-13.

Bluck, S., Alea, N., Habermas, T., and Rubin, D. C. (2005). A tale of three functions: the self-reported uses of autobiographical memory. Soc. Cogn. 23, 91-117. doi: $10.1521 /$ soco.23.1.91.59198

Blustein, D. L. (2001). The interface of work and relationships: a critical knowledge base for 21 st century psychology. Counsel. Psychol. 29, 179-192. doi: $10.1177 / 0011000001292001$

Blustein, D. L. (2006). The Psychology of Working: A New Perspective for Career Development, Counseling, and Public Policy. Mahwah, NJ: Erlbaum.

Blustein, D. L., Devenis, L. E., and Kidney, B. A. (1989). Relationship between the identity formation process and career development. J. Counsel. Psychol. 36, 196-202. doi: 10.1037/0022-0167.36.2.196

Blustein, D. L., Palladino Schultheiss, D. E., and Flum, H. (2004). Toward a relational perspective of the psychology of careers and working: a social constructionist analysis. J. Vocat. Behav. 64, 423-440. doi: 10.1016/j.jvb.2003.12.008

Boros, S., Curseu, P. L., and Miclea, M. (2011). Integrative tests of a multidimensional model of organizational identification. Soc. Psychol. 2, 111123. doi: $10.1027 / 1864-9335 / \mathrm{a} 000051$

Bowlby, J. (1988). A Secure Base. London: Routledge.

Brett, J. M., and Stroh, L. K. (2003). Working 61 plus hours a week: why do managers do it? J. Appl. Psychol. 1, 67-78. doi: 10.1037/0021-9010.88.1.67

Brewer, M. B. (1991). The social self: on being the same and different at the same time. Pers. Soc. Psychol. Bull. 17, 475-482. doi: 10.1177/0146167291175001

Brewer, M. B., and Gardner, W. (1996). Who is this "we"? Levels of collective identity and self representations. J. Pers. Soc. Psychol. 71, 83-93. doi: 10.1037/0022-3514.71.1.83

Brown, A. D. (2014). Identities and identity work in organizations. Int. J. Manage. Rev. 17, 20-40. doi: 10.1111/ijmr.12035

Bruner, J. (2004). "Why stories matter in psychotherapy," in The Handbook of Therapy \& Psychotherapy: Practice,Theory, and Research, eds L. Angus and J. McLeod (Thousand Oaks, CA: Sage Publications), 3-14.
Buchanan, B. (1974). Building organizational commitment: the socialization of managers in work organizations. Adm. Sci. Q. 19, 533-546. doi: $10.2307 / 2391809$

Bujold, C. (2004). Constructing career through narrative. J. Vocat. Behav. 64, 470-484. doi: 10.1016/j.jvb.2003.12.010

Burke, P. J., and Stets, J. E. (2009). Identity Theory. New York, NY: Oxford University Press.

Butler, S. (1998). The Way all Flesh. New York, NY: Random House.

Cabinet Office Strategy Unit (2003). Ethnic Minorities and the Labour Market: Final Report. London: Cabinet Office.

Camus, A. (1942). Le Mythe de Sisyphe: The Myth of Sisyphus and other Essays, trans. J. O’Brien. New York, NY: Vintage International.

Canli, T., Zhao, Z., Brewer, J., Gabrielli, J. D., and Cahill, L. (2000). Event-related activation in the human amygdale associates with lateral memory for individual emotional experience. J. Neurosci. 20, 1-5.

Cappelli, P. (2000). Managing without commitment. Organ. Dynam. 4, 11-25. doi: 10.1016/S0090-2616(00)00008-5

Carr, J. Z., Schmidt, A. M., Ford, K., and DeShon, R. P. (2003). Climate perceptions matter: a meta-analytic path analysis relating molar climate cognitive and affective states, and individual level work outcomes. J. Appl. Psychol. 88, 605-619. doi: 10.1037/0021-9010.88. 4.605

Causer, G., and Jones, C. (1996). Management and control of technical labour. Work Employ. Soc. 10, 105-123. doi: 10.1177/0950017096101005

Caza, B. B., and Wilson, M. G. (2009). "Me, myself and I: the benefits of workidentity complexity," in Exploring Positive Identities and Organizations: Building a Theoretical and Research Foundation, eds L. M. Roberts and J. E. Dutton (New York, NY: Routledge), 99-123.

Cheng, C., Sanchez-Burks, J., and Lee, F. (2008). Connecting the dots within: creativity performance and identity integration. Psychol. Sci. 19, 1178-1184. doi: 10.1111/j.1467-9280.2008.02220.x

Cohen, L., Arnold, J., and O'Neill, M. (2011). Migration: vocational perspectives on a complex and diverse transition. J. Vocat. Behav. 78, 321-324. doi: 10.1016/j.jvb.2011.03.011

Cochran, L. (1991). Life-Shaping Decisions. New York, NY: Peter Lang.

Cochran, L. (1992). The career project. J. Career Dev. 18, 187-197. doi: 10.1007/BF01321711

Cochran, L. (1997). Career Counselling: A Narrative Approach. Thousand Oaks, CA: Sage Publications.

Collin, K. (2008). Work-related identity in individual and social learning at work. J. Workplace Learn. 1, 23-35.

Collin, K., Paloniemi, S., Virtanen, A., and Eteläpelto, A. (2008). Constraints and challenges on learning and construction of identities at work. Vocat. Learn. 3, 191-210. doi: 10.1007/s12186-008-9011-4

Conway, M. A. (2005). Memory and the self. J. Mem. Lang. 53, 594-628. doi: 10.1016/j.jml.2005.08.005

Conway, M. A., and Holmes, A. (2004). Psychosocial stages and the accessibility of autobiographical memories across the life cycle. J. Pers. 3, 461-480. doi: 10.1111/j.0022-3506.2004.00269.x

Conway, M. A., Singer, J. A., and Tagini, A. (2004). The self and autobiographical memory: correspondence and coherence. Soc. Cogn. 22, 495-537. doi: 10.1521/soco.22.5.491.50768

Cremer, D. D. (2006). Unfair treatment and revenge taking: the roles of collective identification and feelings of disappointment. Group Dyn. 3, 220-232. doi: 10.1037/1089-2699.10.3.220

Cremer, D. D., van Knippenberg, D., van Dijke, M., and Bos, A. E. R. (2006). Selfsacrificial leadership and follower self-esteem: when collective identification matters. Group Dyn. 3, 233-245. doi: 10.1037/a0014782

D'Argembeau, A., and Salmon, E. (2012). "The neural basis of semantic and episodic forms of self-knowledge," in Sensing in Nature, ed. C. López-Larrea (Berlin: Springer), 276-290.

Day, C., Kington, A., Stobart, G., and Sammons, P. (2006). The personal and professional selves of teachers: stable and unstable identities. Br. Educ. Res. J. 4, 601-616. doi: 10.1080/01411920600 775316

du Gay, P. (1996). Consumption and Identity at Work. London: Sage Publication. Di Fabio, A., and Bernaud, J.-L. (2014). The Construction of Identity in 21st Century: A Festschrift for Jean Guichard. New York: Nova Science Publishers. 
Di Fabio, A., and Kenny, M. E. (2015). The contributions of emotional intelligence and social support for adaptive career progress among Italian youth. J. Career Dev. 42, 48-49. doi: 10.1177/0894845314 533420

Di Fabio, A., and Maree, J. G. (2012). Group-based Life Design Counseling in an Italian context. J. Vocat. Behav. 80, 100-107. doi: 10.1016/j.jvb.2011.06.001

Di Fabio, A., and Maree, J. G. (2013). Psychology of Career Counselling: New Challenges for a New era. Festschrift in Honour of Mark Savickas. New York, NY: Nova Science Publishers.

Di Fabio, A., and Saklofske, D. H. (2014). Comparing ability and self-report trait emotional intelligence, fluid intelligence, and personality traits in career decision. Pers. Individ. Differ. 64, 174-178. doi: 10.1016/j.paid.2014.02.024

Diestel, S., Wegge, J., and Schmidt, K.-H. (2013). The impact of social context on the relationship between individual job satisfaction and absenteeism: the roles of different foci of job satisfaction and workunit absenteeism. Acad. Manage. J. 57, 353-382. doi: 10.5465/amj.2010. 1087

Dik, B. J., and Duffy, R. D. (2009). Calling and vocation at work. Counsel. Psychol. $3,424-450$.

Dutton, J. E., Roberts, L. M., and Bednar, J. (2010). Pathways for positive identity construction at work: Four types of positive identity and the building of social resources. Acad. Manage. Rev. 2, 265-293. doi: 10.5465/AMR.2010.484 63334

Edwards, H., and Dirette, D. (2010). The relationship between professional identity and burnout among occupational therapists. Occupational Therapy in Health Care 24, 119-129. doi: 10.3109/07380570903329610

Edwards, M. R. (2005). Organizational identification: a conceptual and operational review. Int. J. Manage. Rev. 4, 207-230. doi: 10.1111/j.1468-2370.2005.00114.x

Ellemers, N., de Gilder, D., and Haslam, S. A. (2004). Motivating individuals and groups at work: A social identity perspective on leadership and group performance. Acad. Manage. Rev. 29, 459-478. doi: 10.5465/AMR.2004.13670967

Erikson, E. H. (1968). Identity: Youth and Crisis. New York, NY: Norton.

Escartín, J., Ullrich, J., Zapf, D., Schlüter, E., and van Dick, R. (2013). Individualand group-level effects of social identification on workplace bullying. Eur. J. Work Organ. Psychol. 2, 182-193. doi: 10.1080/1359432X.2011.647407

Farmer, A. M., and Van Dyne, L. (2010). The idealized self and the situated self as predictors of employee work behaviors. J. Appl. Psychol. 3, 503-516. doi: $10.1037 / \mathrm{a} 0019149$

Fenwick, T. (2004). Learning in portfolio work: anchored innovation and mobile identities. Stud. Contin. Educ. 2, 229-241. doi: 10.1080/158037042000225236

Fine, G. A. (1996). Justifying work: occupational rhetorics as recources in restaurant kitchens. Adm. Sci. Q. 41, 90-115. doi: 10.2307/2393987

Fishbach, A., Henderson, M. D., and Koo, M. (2011). Pursuing goals with others: group identification and motivation resulting from things done versus things left undone. J. Exp. Psychol. 3, 520-534. doi: 10.1037/a0023907

Fivush, R. (2008). Remembering and reminiscing: how individual lives are constructed in family narratives. Mem. Stud. 1, 45-54. doi: $10.1080 / 00207594.2011 .596541$

Fivush, R. (2011). The development of autobiographical memory. Annu. Rev. Psychol. 62, 559-582. doi: 10.1146/annurev.psych.121208.131702

Flum, H. (2001). Relational dimensions in career development. J. Vocat. Behav. 59, 1-16. doi: 10.1006/jvbe.2000.1786

Flum, H., and Cinamon, R. G. (2011). Immigration and the interplay among citizenship, identity and career: the case of Ethiopian immigration to Israel. J. Vocat. Behav. 78, 372-380. doi: 10.1016/j.jvb.2011.03.014

Fouad, N. A., and Bynner, J. (2008). Work transitions. Am. Psychol. 4, 241-251. doi: 10.1037/0003-066X.63.4.241

Foud, N. A. (2007). Work and vocational psychology: theory, research and practice. Annu. Rev. Psychol. 58, 543-564. doi: 10.1146/annurev.psych.58.110405.085713

Friedland, D. S., and Price, R. H. (2003). Underemployment: consequences for the health and well-being of workers. Am. J. Commun. Psychol. 32, 33-45. doi: 10.1023/A:1025638705649

Gao, Y. F., and Riley, M. (2009). Knowledge and identity: a review. Int. J. Manage. Rev. 12, 317-334. doi: 10.1111/j.1468-2370.2009.00265.x

Gecas, V. (1982). The self-concept. Annu. Rev. Soc. 8, 1-33. doi: 10.1146/annurev.so.08.080182.000245
George, J. M. (1995). Leader positive mood and group performance: the case of customer service. J. Appl. Soc. Psychol. 25, 778-794. doi: 10.1111/j.15591816.1995.tb01775.x

Gini, A. (1998). Work, identity and self: how we are formed by the work we do. J. Bus. Ethics 17, 707-714. doi: 10.1023/A:1017967009252

Goodman, P. S., Lawrence, B. S., Ancona, D. J., and Tushman, M. J. (2001). Introduction: special topic forum on time. Acad. Manage. Rev. 26, 507-511. doi: 10.5465/AMR.2001.5393884

Grant, A. M. (2008). The significance of task significance: job performance, effects, relational mechanisms, and boundary conditions. J. Appl. Psychol. 1, 108-124. doi: 10.1037/0021-9010.93.1.108

Greenhaus, J. H., Peng, A. C., and Allen, T. D. (2012). Relations of work identity, family identity, situational demands, and sex with employee work hours. J. Vocat. Behav. 80, 27-37. doi: 10.1016/j.jvb.2011.05.003

Greenwald, A. G. (1980). The totalitarian ego: fabricitaion and revision of personal history. Am. Psychol. 35, 603-618. doi: 10.1037/0003-066X.35.7.603

Grice, H. P. (1941). Personal identity. Mind 50, 330-350. doi: $10.1093 / \mathrm{mind} / \mathrm{L} .200 .330$

Guichard, J. (2009). Self-constructing. J. Vocat. Behav. 75, 251-258. doi: 10.1016/j.jvb.2009.03.004

Habermas, T., and Bluck, S. (2000). Getting a life: the emergence of the life story in adolescence. Psychol. Bull. 5, 748-769. doi: 10.1037/0033-2909.126.5.748

Hackman, J. R., and Oldham, G. R. (1976). Motivation through the design of work: test of a theory. Organ. Behav. Hum. Perform. 16, 250-279. doi: 10.1016/00305073(76)90016-7

Hackman, J. R., and Oldham, G. R. (1980). Work Redesign. Reading, MA: AddisonWesley.

Hammond, K. R. (2007). Beyond Rationality: The Search for Wisdom in a Troubled Time. New York, NY: Oxford University Press.

Harquail, C. V. (1998). "Organizational identification and the "whole person": integrating affect, behaviour, and cognition," in Identity in Organizations: Building Theory Through Conversations, eds D. A. Whetten and P. C. Godfrey (Thousand Oaks, CA: Sage Publication), 223-231.

Haslam, S. A. (2001). Psychology in Organizations: The Social Identity Approach. London: Sage Publications.

Haslam, S. A., Jetten, J., Postmes, T., and Haslam, C. (2009). Social identity, health and well-being: an emerging agenda for applied psychology. Appl. Psychol. 58, 1-23. doi: 10.1111/j.1464-0597.2008.00379.x

Haslam, S. A., Powell, C., and Turner, J. C. (2000). Social identity, selfcategorization and work motivation: rethinking the contribution of the group to positive and sustainable organizational outcomes. Appl. Psychol. 49, 319-339. doi: 10.1111/1464-0597.00018

Heine, S. J., Proulx, T., and Vohs, K. D. (2006). The meaning maintenance model: on the coherence of social motivations. Pers. Soc. Psychol. Rev. 2, 88-110. doi: $10.1207 / \mathrm{s} 15327957 \mathrm{pspr} 1002 \_1$

Henke, K. (2010). A model for memory systems based on processing modes rather than consciousness. Nat. Rev. 11, 523-532. doi: 10.1038/nrn2850

Higgins, E. T., and Bargh, J. A. (1987). Social cognition and social perception. Annu. Rev. Psychol. 38, 369-425. doi: 10.1146/annurev.ps.38.020187.002101

Hogg, M. (2003). "Social identity," in Handbook of Self and Identity, eds R. Mark, Leary, P. June, and Tangney (New York, NJ: The Guilford Press), 462-479.

Hogg, M. (2006). "Social identity theory," in Contemporary Social Psychological Theories, ed. P. J. Burke (Palo Alto, CA: Standford University Press), 111-136.

Hogg, M., and Abrams, D. (1988). Social Identifications: A Social Psychology of Intergroup Relations and Group Processes. London: Routledge.

Ibarra, H. (1999). Provisional selves: experimenting with image and identity in professional adaptation. Adm. Sci. Q. 44, 764-791. doi: 10.2307/2667055

Jackson, C. L., Colquitt, J. A., Wesson, M. J., and Zapata-Phelan, C. P. (2006). Psychological collectivism: a measurement validation and linkage to group member performance. J. Appl. Psychol. 91, 884-899. doi: 10.1037/00219010.91.4.884

Jackson, J. W. (2002). Intergroup attitudes as a function of different dimensions of group identification and perceived intergroup conflict. Self Identity 1, 11-34. doi: $10.1080 / 152988602317232777$

James, W. (1890/1950). The Principles of Psychology. New York, NY: Dover.

Jetten, J., O'Brien, A., and Trindall, N. (2002). Changing identity: Precting adjustment to organizational restructure as a function of subgroup 
and super ordinate identification. Br. J. Soc. Psychol. 41, 281-297. doi: $10.1348 / 014466602760060147$

Johns, G. (1997). "Contemporary research on absence from work: correlates, causes, and consequences," in International Review of Industrial and Organizational Psychology, Vol. 12, eds C. L. Cooper and I. I. Robertson (Chichester: Wiley), 115-173.

Johnson, M. D., Morgeson, F. P., Ilgen, D. R., Meyer, C. J., and Lloyd, J. W. (2006). Multiple professional identities: examining differences in identification across work-related targets. J. Appl. Psychol. 2, 498-506. doi: 10.1037/00219010.91.2.498

Johnson, R. E., and Jackson, E. M. (2009). Appeal of organizational values is in the eye of the beholder: the moderating role of employee identity. J. Occup. Organ. Psychol. 82, 915-933. doi: 10.1348/096317908X373914

Johnson, R. E., and Lord, R. G. (2010). Implicit effects of justice on self-identity. J. Appl. Psychol. 4, 681-695. doi: 10.1037/a0019298

Kant, I. (1787/1929). Critique of Pure Reason. London: The MacMillian Press Ltd.

Kavanaugh, J., Duffy, J. A., and Lilly, J. (2006). The relations between job satisfaction and demographic variables for healthcare professionals. Manage. Res. News 6, 304-325. doi: 10.1108/014091706106 83842

Kelchtermans, G. (1993). Getting the story, understanding the lives: from career stories to teachers' professional development. Teach. Teacher Educ. 9, 443-456. doi: 10.1016/0742-051X(93)90029-G

Kenny, E. J., and Briner, R. B. (2007). Ethnicity and behavior in organizations: a review of British research. J. Occup. Organ. Psychol. 80, 437-457. doi: 10.1348/096317906X156313

Kidd, J. M. (1998). Emotion: an absent presence in career theory. J. Vocat. Behav. 52, 275-288. doi: 10.1006/jvbe.1997.1629

Kihlstrom, J. F. (2012). Searching for the self in mind and brain. Soc. Cogn. 4, 367-379. doi: 10.1521/soco.2012.30.4.367

Kihlstrom, J. F., Beer, J. S., and Klein, S. B. (2003). "Self and identity as memory," in Handbook of Self and Identity, eds M. R. Leary and J. P. Tangney (New York, NY: The Guilford Press), 68-90.

Kihlstrom, J. F., and Klein, S. B. (1994). "The self as a knowledge structure," in Handbook of Social Cognition, Vol. 1, eds R. S. Wyer and T. K. Srull (Hillsdale, NJ: Erlbaum), 153-208.

Kim, S. S., and Gelfand, M. J. (2003). The influence of ethnic identity on perceptions of organizational recruitment. J. Vocat. Behav. 63, 396-416. doi: 10.1016/S00018791(02)00043-X

King, L. A., Hicks, J. A., Krull, J., and Del Gaiso, A. K. (2006). Positive affect and the experience of meaning in life. J. Pers. Soc. Psychol. 90, 179-196. doi: 10.1037/0022-3514.90.1.179

Kira, M., and Balkin, D. B. (2014). Interactions between work and identities: thriving, withering, or redefining the self? Hum. Resour. Manage. Rev. 24, 131-143. doi: 10.1016/j.hrmr.2013.10.001

Kirpal, S. (2004). Work identities of nurses: between caring and efficiency demands. Career Dev. Int. 3, 274-304. doi: 10.1108/13620430410535850

Kirpal, S., Brown, A., and Dif, M. (2007). "The individualisation of identification with work in a European perspective," in Identities at Work, eds A. Brown, S. Kirpal, and F. Rauner (Dordrecht: Springer), 285-313.

Klein, S. B. (2001). "A self to remember: a cognitive neuropsychological perspective on how self creates memory and memory creates self," in Individual Self, Relational Self, Collective Self, eds C. Sedikides and M. B. Brewer (Philadelphia, PA: Psychology Press), 25-46.

Klein, S. B. (2012). The self and its brain. Soc. Cogn. 30, 474-516. doi: 10.1521/soco.2012.30.4.474

Klein, S. B. (2013). Making the case that episodic recollection is attributable to operations occurring at retrieval than to content stored in a dedicated subsystem of long-term memory. Front. Behav. Neurosci. 7:3. doi: 10.3389/fnbeh.2013.00003

Klein, S. B. (2014a). Sameness and the self: philosophical and psychological considerations. Front. Psychol. 5:29. doi: 10.3389/fpsyg.2014.00029

Klein, S. B. (2014b). The Two Selves: Their Metaphysical Commitments and Functional Independence. New York, NY: Oxford University Press.

Klein, S. B., and Gangi, S. (2010). The multiplicity of self: neuropsychological evidence and its implications for the self as a construct in psychological research. Ann. N. Y. Acad. Sci. 1191, 1-15. doi: 10.1111/j.1749-6632.2010.05441.x
Klein, S. B., German, T. P., Cosmides, L., and Gabriel, R. (2004). A theory of autobiographical memory: Necessary components, and disorders resulting from their loss. Soc. Cogn. 5, 460-490. doi: 10.1521/soco.22.5.460.50765

Klein, S. B., and Lax, M. L. (2010). The unanticipated resilience of trait self-knowledge in the face of neural damage. Memory 18, 918-948. doi: 10.1080/09658211.2010.524651

Klein, S. B., and Loftus, J. (1993). "The mental representation of trait and autobiographical knowledge about the self," in Advances in Social Cognition, eds T. K. Srull and R. S. Wyer (Hillsdale, NJ: Erlbaum), 1-49.

Klein, S. B., Loftus, J., and Kihlstrom, J. F. (2002). Memory and temporal experience: the effects of episodic memory loss on an amnesic patient's ability to remember the past and imagine the future. Soc. Cogn. 5, 353-379. doi: 10.1521/soco.20.5.353. 21125

Knez, I. (2005). Attachment and identity as related to a place and its perceived climate. J. Environ. Psychol. 25, 207-218. doi: 10.1016/j.jenvp.2005.03.003

Knez, I. (2006). Autobiographical memories for places. Memory 14, 359-377. doi: $10.1080 / 09658210500365698$

Knez, I. (2014). Place and the self: an autobiographical memory synthesis. Philos. Psychol. 2, 164-192. doi: 10.1080/09515089.2012.728124

Kotter, J. P. (1990). A Force for Change: How Leadership Differs from Management. New York, NY: Free Press.

Kroger, J. (2007). Identity Development: Adolescence Through Adulthood. Thousand Oaks, CA: Sage Publications.

Law, K. S., Wong, C. S., and Mobley, W. H. (1998). Toward a taxonomy of multidimensional constructs. Acad. Manage. Rev. 23, 741-755. doi: 10.5465/AMR.1998.1255636

Leary, M. R., and Tangney, J. P. (eds). (2003). Handbook of Self and Identity. New York: The Guilford Press.

Leung, K., Chiu, W., and Au, Y. (1993). Sympathy and support for industrial actions: a justice analysis. J. Appl. Psychol. 78, 781-787. doi: 10.1037/00219010.78.5.781

Lipponen, J., Helkama, K., Olkkonen, M.-E., and Juslin, M. (2005). Predicting the different profiles of organizational identification: a case of shipyard subcontractors. J. Occup. Organ. Psychol. 78, 97-112. doi: 10.1348/096317904X22935

Locke, J. (1690/1849). An Essay Concerning Human Understanding. Philadelphia: Kay and Troutman.

Lucas, R. E., Clark, A. E., Georgellis, Y., and Diener, E. (2004). Unemployment alters the set point for life satisfaction. Psychol. Sci. 15, 8-13. doi: 10.1111/j.09637214.2004.01501002.x

Luyckx, K., Duriez, B., Klimstra, T. A., and Witte, H. D. (2010). Identity statuses in young adult employees: prospective relations with work engagement and burnout. J. Vocat. Behav. 77, 339-349. doi: 10.1016/j.jvb.2010. 06.002

Mael, F. A., and Ashforth, B. E. (1992). Alumni and their alma mater: a partial test of the reformulated model of organizational identification. J. Organ. Behav. 13, 103-123. doi: 10.1002/job.4030130202

Mael, F. A., and Ashforth, B. E. (1995). Loyal from day one: Biodata, organizational identification, and turnover among newcomers. Pers. Psychol. 48, 309-333. doi: 10.1111/j.1744-6570.1995.tb01759.x

Mahoney, M. J. (2002). "Constructivism and positive psychology," in Handbook of Positive Psychology, eds C. R. Snyder and S. J. Lopez (Oxford: Oxford University Press), $745-750$

Marcia, J. E. (1980). "Identity in adolescence," in Handbook of Adolescent Psychology, ed. J. Adelson (New York, NY: Wiley), 159-187.

Markowitsch, H. J., and Staniloiu, A. (2011). Memory, autonoetic consciousness, and the self. Conscious. Cogn. 20, 16-39. doi: 10.1016/j.concog.2010.09.005

Markus, H. R., and Nurius, P. (1986). Possible selves. Am. Psychol. 9, 954-969. doi: 10.1037/0003-066X.41.9.954

Marris, P. (1982). "Attachment and society," in The Place Attachment in Human Behavior, eds C. M. Parker and J. Stevenson-Hinde (London: Tavistock Publications), 185-201.

Mathews, B. P., and Shepherd, J. L. (2002). Dimensionality of Cook and Wall's(1980) British organizational commitment scale revised. J. Occup. Organ. Psychol. 75, 369-375. doi: 10.1348/096317902320369767

May, D. R., Gilson, L., and Harter, L. M. (2004). The psychological conditions of meaningfulness, safety and availability and the engagement of the human 
spirit at work. J. Occup. Organ. Psychol. 77, 11-37. doi: 10.1348/0963179043229 15892

McAdams, D. P. (1995). What do we know when we know a person? J. Pers. 63, 365-396. doi: 10.1111/jopy.12018

McAdams, D. P. (2006). The Redemptive Self: Stories Americans Live by. New York, NY: Oxford University Press.

McConnell, A. R. (2011). The multiple self-aspects framework: self-concept representation and its implications. Pers. Soc. Psychol. Rev. 1, 3-27. doi: $10.1177 / 1088868310371101$

McCormack, T., and Hoerl, C. (1999). Memory and temporal perspective: the role of temporal frameworks in memory development. Dev. Rev. 19, 154-182. doi: 10.1006/drev.1998.0476

McLain, D. L. (1995). Responses to health and safety risk in the work environment. Acad. Manage. J. 38, 1726-1746. doi: 10.2307/256852

Meyer, J., and Allen, N. (1991). A three component conceptualisation of organizational commitment. Hum. Resour. Manage. Rev. 1, 61-89. doi: 10.1016/1053-4822(91)90011-Z

Michinov, N., Michinov, E., and Toczek-Capelle, M.-C. (2004). Social identity, group processes, and performance in synchronous computer-mediated communication. Group Dyn. 1, 27-39. doi: 10.1037/1089-2699.8.1.27

Mobley, W. H., Griffeth, R. W., Hand, H. H., and Meglino, B. M. (1979). Review and conceptual analysis of the employee turnover process. Psychol. Bull. 86, 493-522. doi: 10.1016/j.ijnurstu.2015.02.012

Mowday, R., Steers, R., and Porter, L. (1982). Employee-Organisation Linkages: The Psychology of Commitment, Absenteeism and Turnover. London: Academic Press.

Mullen, B. (1991). Group composition, salience and cognitive representations: the phenomenology of being in a group. J. Exp. Soc. Psychol. 27, 297-323. doi: 10.1016/0022-1031(91)90028-5

Murphy, G. C., and Athanasou, J. A. (1999). The effect of unemployment on mental health. J. Occup. Organ. Psychol. 72, 83-99. doi: 10.1348/096317999166518

Neisser, U. (1988). Five kinds of self-knowledge. Philos. Psychol. 1, 35-59. doi: 10.1080/09515088808572924

Obschonka, M., Goethner, M., Silbereisen, R. K., and Cantner, U. (2012). Social identity and the transition to entrepreneurship: the role of group identification with workplace peers. J. Vocat. Behav. 80, 137-147. doi: 10.1016/j.jvb.2011. 05.007

Olkkonen, M.-E., and Lipponen, J. (2006). Relationships between organizational justice, identification with organization and work unit, and group-related outcomes. Organ. Behav. Hum. Decis. Process. 100, 202-215. doi: 10.1016/j.obhdp.2005. 08.007

Onorato, R. S., and Turner, J. C. (2001). "The "I", the "me", and the "us": the psychological group and self-concept maintenance and change," in Individual Self, Relational Self, Collective Self, eds C. Sedikides and M. B. Brewer (Philadelphia, PA: Psychology Press), 147-170.

Onorato, R. S., and Turner, J. C. (2004). Fluidity in the self-concept: the shift from personal to social identity. Eur. J. Soc. Psychol. 34, 257-278. doi: 10.1002/ejsp.195

Parker, C. P., Baltes, B. B., Young, S. A., Huff, J. W., Altmann, R. A., LaCosta, H. A., et al. (2003). Relationships between psychological climate perceptions and work outcomes: a meta-analytic review. J. Organ. Behav. 24, 389-416. doi: 10.1002/job.198

Pate, J., Beaumont, P., and Pryce, G. (2009). Organisations and the issue of multiple identities: who loves you baby? VINE 4, 319-388. doi: 10.1108/03055720911013625

Paul, K. I., and Moser, K. (2009). Unemployment impairs mental health: metaanalyses. J. Vocat. Behav. 74, 264-282. doi: 10.1016/j.jvb.2009.01.001

Plug, W., Zeijl, E., and Du Bois-Reymond, M. (2003). Young people's perceptions on youth and adulthood: a longitudinal study from the Netherlands. J. Youth Stud. 6, 127-144. doi: 10.1080/1367626032000 110273

Pratt, M. G. (1998). “To be or not to be? Central questions in organizational identification," in Identity in Organizations: Building Theory Through Conversations, eds D. A. Whetten and P. C. Godfrey (Thousand Oaks, CA: Sage Publication), 171-207.

Pratt, M. G. (2000). The good, the bad, and the ambivalent: managing identification among Amway distributors. Adm. Sci. Q. 45, 456-493. doi: 10.2307/2667106
Pratt, M. G. (2001). "Social identity dynamics in modern organizations: an organizational osychology-organizational behavior perspective," in Social Identity Processes in Organizational Contexts, eds M. A. Hogg and D. J. Terry (Philadelphia: Psychology Press), 13-30.

Prebble, S. C., Addis, D. R., and Tippett, L. J. (2013). Autobiographical memory and sense of self. Psychol. Bull. 4, 815-840. doi: 10.1037/a00 30146

Ravasi, D., and Canato, A. (2013). How do I know who you think you are? A review methods on organizational identity. Int. J. Manage. Rev. 15, 185-204. doi: $10.1111 /$ ijmr.12008

Reichers, A. E. (1985). A review and reconceptualization of organizational commitment. Acad. Manage. Rev. 10, 465-476. doi: 10.2307/258128

Reid, A., and Deaux, K. (1996). Relationship between social and personal identities: segregation or integration? J. Pers. Soc. Psychol. 6, 1084-1091. doi: 10.1037/0022-3514.71.6.1084

Riketta, M., and Dick, R. V. (2005). Foci of attachment in organizations: a meta-analytic comparison of the strength and correlates of workgroup versus organizational identification and commitment. J. Vocat. Behav. 3, 490-510. doi: 10.1016/j.jvb.2004.06.001

Roberson, L. (1990). "Functions of work meanings in organizations: work meanings and work motivation," in Meanings of Occupational Work, eds A. P. Brief and W. R. Nord (Lexington: Lexington Books), 107-134.

Rosenberg, M. (1979). Conceiving the Self. New York, NY: Basic Books.

Rosso, B. D., Dekas, K. H., and Wrzesniewski, A. (2010). On the meaning of work: a theoretical integration and review. Res. Organ. Behav. 30, 91-127. doi: 10.1016/j.riob.2010.09.001

Rousseau, D. M. (1998). Why workers still identify with organizations. J. Organ. Behav. 19, 217-233. doi: 10.1002/(SICI)1099-1379(199805)19

Ryan, R. M., and Deci, E. L. (2001). “To be happy or to be self-fulfilled: a review of research on hedonic and eudaimonic well-being," in Annual Review of Psychology, Vol. 52, ed. S. Fiske (Palo Alto, CA: Annual Reviews Inc), 141-166.

Savickas, M. L. (1985). Identity in vocational development. J. Vocat. Behav. 27, 329-337. doi: 10.1016/0001-8791(85)90040-5

Savickas, M. L. (2001). “Toward a comprehensive theory of careers: dispositions, concerns, and narratives," in Contemporary Models in Vocational Psychology: A Volume in Honour of Samual H. Osipow, eds F. T. L. Leong and A. Barak (Mahwah, NJ: Erlbaum), 295-320.

Savickas, M. L. (2002). “Career construction: A developmental theory of vocational behaviour," in Career Choice and Development, eds D. Brown and Associates (San Francisco, CA: Jossey-Bass), 149-205.

Savickas, M. L. (2005). "The theory and practice of career construction," in Career Development and Counseling: Putting Theory and Research to Work, eds S. D. Brown and R. W. Lent (Hoboken, NJ: Wiley), 42-70.

Savickas, M. L., Nota, L., Rossier, J., Dauwalder, J. P., Duarte, M. E., Guichard, J., et al. (2009). Life designing: a paradigm for career construction in the 21st century. J. Vocat. Behav. 75, 239-250. doi: 10.1016/j.jvb.2009. 04.004

Schwartz, S. H. (1999). A theory of cultural values and some implications for work. Appl. Psychol. Int. Rev. 48, 23-47. doi: 10.1111/j.1464-0597.1999.tb0 0047.x

Sedikides, C., and Brewer, M. B. (eds). (2001). Individual Self, Relational Self, Collective Self. Philadelphia, PA: Psychology Press.

Sedikides, C., and Gaertner, L. (2001). "A homecoming to the individual self," in Individual Self, Relational Self, Collective Self, eds C. Sedikides and M. B. Brewer (Philadelphia, PA: Psychology Press), 7-24.

Sedikides, C., and Skowronski, J. J. (2003). "Evolution of the symbolic self: Issues and prospects," in Handbook of Self and Identity, eds M. R. Leary and J. P. Tangney (New York, NY: The Guilford Press), 594-609.

Sfard, A., and Prusak, A. (2005). Telling identities: In a search of an analytic tool for investigating learning as a culturally shaped activity. Educ. Res. 34, 14-22. doi: 10.3102/0013189X034004014

Shapiro, E. C., Haseltine, F. P., and Rowe, M. P. (1978). Moving up: role models, mentors, and the "patron system". Sloan Manage. Rev. 3, 51-58.

Siegall, M., and McDonald, T. (1995). Focus of attention and employee reactions to job change. J. Appl. Soc. Psychol. 25, 1121-1141. doi: 10.1111/j.15591816.1995.tb02610.x

Sinclar, N. (2008). The changing face of KM. VINE 1, 22-29. doi: $10.1108 / 03055720810870860$ 
Skarlicki, D. P., and Folger, R. (1997). Retaliation in the workplace: the roles of distribute, procedural, and interactional justice. J. Appl. Psychol. 82, 434-443. doi: 10.1037/0021-9010.82.3.434

Skorikov, V. B., and Vondracek, F. W. (2007). "Vocational identity," in Career Development in Childhood and Adolescence, eds V. B. Skorikov and W. Patton (Rotterdam: Sense Publicatioons), 143-168.

Sluss, D. M., and Ashforth, B. E. (2007). Relational identity and identification: defining ourselves through work relationships. Acad. Manage. Rev. 32, 9-32. doi: 10.5465/AMR.2007.23463672

Smith, E. R., Coats, S., and Murphy, J. (2001). "The self and attachment to relationship partners and groups: theoretical parallels and new insight," in Individual Self, Relational Self, Collective Self, eds C. Sedikides and M. B. Brewer (Philadelphia, PA: Psychology Press), 109-124.

Smith, P. C., Kendall, L. M., and Hulin, C. L. (1969). Measurement of Satisfaction in Work and Retirement. Chicago, IL: Rand McNally.

Spears, R. (2001). "The interaction between the individual and the collective self: self-categorization in context," in Individual Self, Relational Self, Collective Self, eds C. Sedikides and M. B. Brewer (Philadelphia, PA: Psychology Press), 171-198.

Squire, L. R. (1992). Declarative and non-declarative memory: multiple brain systems supporting learning, and memory. J. Cogn. Neurosci. 4, 232-243. doi: 10.1162/jocn.1992.4.3.232

Stajkovic, A. (2006). Development of a core confidence-higher order construct. J. Appl. Psychol. 6, 1208-1224. doi: 10.1037/0021-9010.91.6.1208

Staw, B., and Salancik, G. (1977). New Directions in Organizational Behavior. Chicago: St Clair Press.

Suddendorf, T., and Corballis, M. C. (2007). The evolution of foresight: what is mental time travel, and is it unique to humans? Behav. Brain Sci. 30, 299-313. doi: $10.1017 /$ S0140525X07001975

Sealy, R. H. V., and Singh, V. (2009). The importance of role models and demographic context for senior women's work identity development. Int. J. Manag. Rev. 12, 284-300. doi: 10.1111/j.1468-2370.2009.00262.x

Super, D. E. (1990). "A Life-span, life-space approach to career development," in Career Choice and Development, eds D. Brown and L. Brooks (San Francisco: Jossey-Bass), 197-261.

Swann, W. B. Jr., and Bosson, J. (2010). "Self and Identity," in Handbook of Social Psychology, eds S. T. Fiske, D. T. Gilbert, and G. Lindzey (New York, NY: McGraw-Hill), 589-628.

Swann, W. B., Polzer, J. T., Seyle, D. C., and Ko, S. J. (2004). Finding value in diversity: Verification of personal and social self-views in diverse groups. Acad. Manage. Rev. 29, 9-27. doi: 10.5465/AMR.2004.11851702

Tajfel, H. (1978). Differentiation Between Social Groups: Studies in the Social Psychology of Intergroup Relations. London: Academic Press.

Tajfel, H., and Turner, J. C. (1979). "An integrative theory of intergroup conflict," in The Social Psychology of Intergroup Relations, eds W. G. Austin and S. Worchel (Monterey, CA: Brooks/Cole), 33-47.

Tajfel, H., and Turner, J. C. (1986). "The social identity theory of intergroup behavior," in Psychology of Intergroup Behavior, eds S. Worchel and W. G. Austin (Chicago: Nelson), 7-24.

Terry, D. J., and Hogg, M. A. (1996). Group-norms and the attitude-behavior relationship: a role of group identification. Pers. Soc. Psychol. Bull. 22, 776-793. doi: $10.1177 / 0146167296228002$

Tice, D. M., and Baumeister, R. F. (2001). "The primacy of the interpersonal self," in Individual Self, Relational Self, Collective Self, eds C. Sedikides and M. B. Brewer (Philadelphia, PA: Psychology Press), 71-88.

Tripp, T. M., and Bies, R. J. (1997). "What's good about revenge? The avenger's perspective," in Research on Negotiation in Organizational Behavior, eds R. J. Lewicki, R. J. Bies, and B. H. Sheppard (Stamford, CT: JAI Press), 201-246.

Tulving, E. (1972). "Episodic and semantic memory," in Organization of Memory, eds E. Tulving and W. Donaldson (New York: Academic Press), 381-403.

Tulving, E. (1983). Elements of Episodic Memory. New York, NY: Oxford University Press.

Tulving, E. (1985). Memory and consciousness. Can. Psychol. 26, 1-12. doi: $10.1037 / \mathrm{h} 0080017$

Turner, J. C. (1982). "Toward a cognitive redefinition of the social group," in Social Identity and Intergroup Relations, ed. H. Tajfel (Cambridge: Cambridge University Press), 15-40.
Turner, J. C., Oakes, P. J., Haslam, S. A., and McGarty, C. (1994). Self and collective: cognition and social context. Pers. Soc. Psychol. Bull. 20, 454-463. doi: $10.1177 / 0146167294205002$

van Dick, R. (2001). Identification in organizational context: linking theory and research from social and organizational psychology. Int. J. Manage. Rev. 4, 265-283. doi: 10.1111/1468-2370.00068

van Dick, R. (2004). "My job is my castle: identification in organizational contexts," in International Review of Industrial and Organizational Psychology, Vol. 17, eds C. L. Cooper and I. T. Robertson (Chichester: Wiley), 171-204.

van Dick, R., Ullrich, J., and Tissngton, P. A. (2006). Working under a black cloud: how to sustain organizational identification after a merge. Br. J. Manage. 17, 69-79. doi: 10.1111/j.1467-8551.2006.00479.x

van Knippenberg, D. (2000). Work motivation and performance. a social identity perspective. Appl. Psychol. 49, 357-371. doi: 10.1111/1464-0597.00020

van Knippenberg, D. (2003). "Intergroup relations in organizations," in International Handbook of Organizational Teamwork and Cooperative Working, eds M. West, D. Tjosvold, and K. G. Smith (Chichester: Wiley), 381-399.

van Knippenberg, D., and van Schie, E. C. M. (2000). Foci and correlates of organizational identification. J. Occup. Organ. Psychol. 73, 137-147. doi: 10.1348/096317900166949

Van Knippenberg, D. V., Haslam, S. A., and Platow, M. J. (2007). Unity through diversity: value-in-diversity beliefs, work group diversity, and group identification. Group Dyn. 3, 207-222. doi: 10.1037/1089-2699.11.3.207

van Vuuren, M., Beelen, P., and de Jong, M. D. T. (2010). Speaking of dominance, status differences, and identifications: making sense of a merger. J. Occup. Organ. Psychol. 83, 627-643. doi: 10.1348/096317909X463661

Vignoles, V., Manzi, C., Regalia, C., Jemmolo, S., and Scabini, E. (2008). Identity motives underlying desired and feared possible future selves. J. Pers. 76, 11651200. doi: 10.1111/j.1467-6494.2008.00518.x

Vondracek, F. W., Lerner, R. M., and Schulenberg, J. E. (1986). Career Development: A Life-span Developmental Approach. Hillsdale, NJ: Erlbaum.

Wagner, U., and Ward, P. L. (1993). Variation of outgroup presence and evaluation of the in-group. Br. J. Soc. Psychol. 32, 241-251. doi: 10.1111/j.20448309.1993.tb00998.x

Walsh, K., and Gordon, J. R. (2008). Creating and individual work identity. Hum. Resour. Manage. Rev. 18, 46-61. doi: 10.1016/j.hrmr.2007.09.001

Wayne, J. H., Randel, A. E., and Stevens, J. (2006). The role of identity and workfamily support in work-family enrichment and its work-related consequences. J. Vocat. Behav. 69, 445-461. doi: 10.1016/j.jvb.2006.07.002

Wegge, J., Schuh, S. C., and van Dick, R. (2012). "I feel bad", "We feel good"? Emotions as a driver for personal and organizational identity and organizational identification as a resource for serving unfriendly customers. Stress Health 28, 123-136. doi: 10.1002/smi.1412

Wegge, J. R., van Dick, R., Fischer, G. K., Wecking, C., and Moltzen, K. (2006). Work motivation, organizational identification, and well-being in call centre work. Work Stress 20, 60-83. doi: 10.1080/02678370600655553

Weick, K. E. (1995). Sensemaking in Organizations. Thousand Oaks, CA: Sage Publication.

Welzer, H., and Markowitsch, H. J. (2005). Towards a bio-psychosocial model of autobiographical memory. Memory 13, 63-78. doi: $10.1080 / 09658210344000576$

Wheeler, M. A., Stuss, D. T., and Tulving, E. (1997). Toward a theory of episodic memory: the frontal lobes and autonoetic consciousness. Psychol. Bull. 121, 331-354. doi: 10.1037/0033-2909.121.3.331

Williams, H. L., Conway, M. A., and Cohen, G. (2008). "Autobiographical memory," in Memory in the Real World, eds G. Cohen and M. A. Conway (New York, NY: Psychology Press), 21-90.

Williams, K. Y., and O'Reilly, C. A. (1998). Demography and diversity in organizations: a review of 40 years of research. Res. Organ. Behav. 20, 77-140.

Wilson, A. E., and Ross, M. (2003). The identity function of autobiographical memory: time is on our side. Memory 11, 137-149. doi: 10.1080/7419 38210

Wrzesniewski, A., Dutton, J. E., and Debebe, G. (2003). Interpersonal sensemaking and the meaning of work. Res. Organ. Behav. 25, 93-135. doi: 10.1016/S01913085(03)25003-6

Ybarra, O., and Trafimow, D. (1998). How priming the private self or collective self affects the relative weights of attitudes and subjective norms. Pers. Soc. Psychol. Bull. 24, 362-370. doi: $10.1177 / 0146167298244003$ 
Young, R. A., Valach, L., and Collin, A. (2002). "A contextual explanation of career," in Career Choice and Development, eds D. Brown and L. Brooks (San Francisco, CA: Jossey-Bass), 206-252.

Conflict of Interest Statement: The author declares that the research was conducted in the absence of any commercial or financial relationships that could be construed as a potential conflict of interest.
Copyright (c) $2016 \mathrm{Knez}$. This is an open-access article distributed under the terms of the Creative Commons Attribution License (CC BY). The use, distribution or reproduction in other forums is permitted, provided the original author(s) or licensor are credited and that the original publication in this journal is cited, in accordance with accepted academic practice. No use, distribution or reproduction is permitted which does not comply with these terms. 